\title{
Specific Heat and Thermal Conductivity of Explosives, Mixtures, and Plastic-Bonded Explosives Determined Experimentally
}

$\frac{\frac{\sigma}{E}}{\frac{2}{0}}$

$\frac{\lambda}{\infty}$

$\frac{\grave{2}}{5}$ 


\section{DISCLAIMER}

This report was prepared as an account of work sponsored by an agency of the United States Government. Neither the United States Government nor any agency Thereof, nor any of their employees, makes any warranty, express or implied, or assumes any legal liability or responsibility for the accuracy, completeness, or usefulness of any information, apparatus, product, or process disclosed, or represents that its use would not infringe privately owned rights. Reference herein to any specific commercial product, process, or service by trade name, trademark, manufacturer, or otherwise does not necessarily constitute or imply its endorsement, recommendation, or favoring by the United States Government or any agency thereof. The views and opinions of authors expressed herein do not necessarily state or reflect those of the United States Government or any agency thereof. 


\section{DISCLAIMER}

Portions of this document may be illegible in electronic image products. Images are produced from the best available original document. 
This report was not edited by the Technical Information staff.

This report was propared an an aecount of work sponsored by the Unied Suses Government. Neuther the Unitud stures nor the United stuten Dopartment of Enerev, nar anv of their employees, nor unv of their contructure, subecontractors, or their employees, makes any werranty. express or implied, or anumen uny loesul liability or responsibility for the securecy. completeness. or usefulnen: of any information, upparutus. product, or process disclowed, or repreoents thit its use would not infrinee privatelv ow nod gahts. 


\title{
Specific Heat and Thermal Conductivity of Explosives, Mixtures, and Plastic-Bonded Explosives Determined Experimentally
}

\author{
John F. Baytos
}
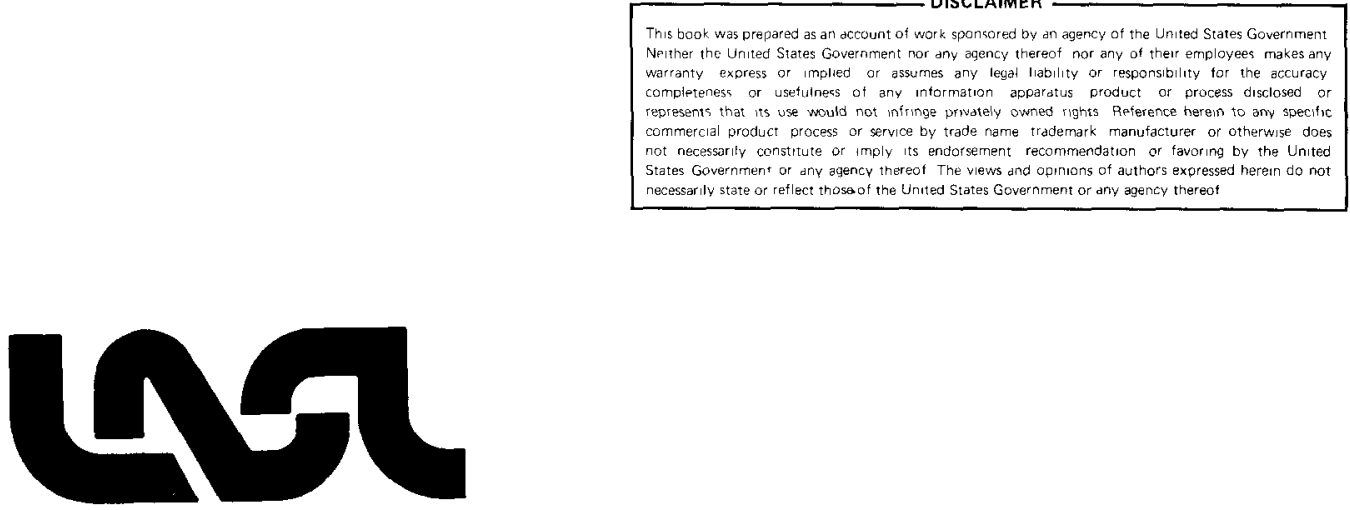
SPECIFIC HEAT AND THERMAL CONDUCTIVITY OF EXPLOSIVES, MIXTURES, AND PLASTIC-BONDED EXPLOSIVES DETERMINED EXPERIMENTALLY

by

John F. Baytos

ABSTRACT

The specific heat and thermal conductivity of explosives and plastic-bonded explosives of interest to wX operations, determined experimentally, are reported in three tables. Specific heat was determined by differential scanning calorimetry against sapphire standards. Thermal conductivity was determined by two means: the guarded hot-plate method or the differential scanning calorimeter comparative method on miniature samples.

I. INTRODUCTION

As new explosives, plastic-bonded explosives, and mixtures are developed and phased into WX-Division operations, the thermal properties are determined. This report summarizes the specific heat and thermal conductivity values for explosives experimentally determined at Group WX-3. Previously published values were used to check our work.

This report also describes the methods used to determine specific heat and thermal conductivity. Details are given of innovations that made the determinations easier to make with safety. The values determined experimentally are presented in three tables.

\section{I DISCUSSION}

Specific heat was determined through the use of a Perkin-Elmer DSC-1B Differential scanning calorimeter (DSC) by the method of o'Neill.1,2 Actual operating directions in the manual ${ }^{3}$ supplied with the instrument were followed.
The DSC was used to make a direct comparison of an unknown sample with a standard sapphire disc at the temperature of interest. The $\mathrm{NBS}^{4}$ value for the specific heat of sapphire was used for the calculation in cgs units $\left(\mathrm{cal} / \mathrm{g}^{\circ} \mathrm{C}\right)$. For SI-derived units ${ }^{5}(\mathrm{~J} / \mathrm{kg} \mathrm{K})$, the cgs value is multiplied by 4184.0 .

specific heat values determined in this way are presented in linear equation form as a function of temperature in Table I, along with the temperature range of the experiments. The standard deviation was calculated from the least-squares fit at midrange.

Thermal conductivity was determined by two methods, the guarded hot-plate (GHP), ASTM $\mathrm{C}-177,6$ and a comparative method adapted for the DSC. 7

The GHP method is primarily a method for measuring the thermal conductivity of insulation board, but has been used for other materials provided that they can be formed into the required sample size. A serious disadvantage of the method for 
measurements on explosives is the use of large samples, which makes it a hazardous operation requiring extraordinary safety precautions. Furthermore, the standard geometry requires that two large-size samples, 8-in. square by 1-in. high, be matched pairs and that the surfaces be plane and parallel. This requirement is especially difficult when the supply of sample material is limited. Another disadvantage of the method is the long equilibration time, usually overnight. Furthermore, temperature and power measurements must be taken until a period of two hours is passed without change, according to the ASTM specifications. For these reasons, only a few samples of explosives were measured in accordance with the ASTM C-177 GHP method. These values are reported in Table $I I$, in cgs units and in sI-derived units ${ }^{5}(\mathrm{~W} / \mathrm{m} \cdot \mathrm{K})$, along with temperature data. SI-derived units are obtained by multiplying cgs units by 418.4. The values are based on our calibration against Teflon [6.02 $\mathrm{x}$ $\left.10^{-4} \mathrm{cal} / \mathrm{s} \mathrm{cm}^{2}\left({ }^{\circ} \mathrm{C} / \mathrm{cm}\right)\right]$ at several temperatures that agree with the values reported by Eierman. 8

Because sample size and the associated safety hazards were a problem, we looked for a method that uses smaller samples. A comparative method meeting these requirements was reported by Brennan, Miller, and Whitwell, 7 who describe the use of the DSC for making thermal conductivity measurements. The method uses the DSC to regulate the heat flow entering two samples resting on separate heating platens, mounted side by side, ${ }^{9}$ to which are attached resistance thermometers. The thermometers sense the temperature of the hot surface, and a servo amplifier monitors the power to maintain each heater at the designated test temperature. The output signal of the DSC control unit is a voltage proportional to the power needed to keep the system isothermal. The cold surface temperature readings come from thermocouples in a cold sink resting on top of the samples in the test cell. When the experiment comes to steady-state, the temperature gradient, equal for both the sample and the reference, is measured as is the difference in power input to the two heaters. These data, the sample dimensions, and known value of the reference permitted us to calculate the thermal conductivity of the unknown sample on a comparative basis.

The thermal conductivities of explosives determined by this method are presented in Table III; the temperature data and results are in cgs units and SIderived units. The DSC apparatus was calibrated with samples made from sample slabs whose thermal conductivity was measured by the GHP method. Teflon samples cut from a GHP test sample were generally used as the reference. To determine the calorimeter constant, Teflon and other samples of known thermal conductivity were used. The closer the reference value was to the value of the unknown, the less error there was in the experimental result. Because the values measured by using the DSC method agreed well with those from the GHP method, we were able to make measurements on small, readily available samples in much less time.

\section{SPECIFIC HEAT MEASUREMENTS BY DIFFERENTIAL SCANNING CALORIMETER}

Because the method used is detailed in the instrument manufacturer's instructions, only exceptions to the procedure are described here.

For measurements on monolithic materials, 6-mm-diam samples were cut from a 
cast or pressed wafer $0.5-\mathrm{mm}$ thick and then encapsulated in a sample pan. For powdered materials, samples $20-30 \mathrm{mg}$ in weight and encapsulated into pans were an optimum size for satisfactory measurements.

The DSC was calibrated with materials of known specific heat, that is, sapphire, benzoic acid, and triple-recrystallized succinic acid. The differences between our measured and published values were within the error reported by $0^{\prime} \mathrm{Neill}^{1}$ in his calibration.

At each temperature of interest, the specific heat of the unknown was calculated, after making the corrections for the aluminum encapsulation pans containing the unknown and the sapphire samples, by the equation given in the DSC manual. The specific heat of the unknown was calculated at temperatures up to the melting point or to the onset of decomposition of the unknown. When all the data pairs were acquired, a statistical leastsquares equation was computed for the specific heat of the unknown sample as a function of temperature, along with the standard deviation at the midrange temperature.

IV. GUARDED HOT-PLATE METHOD FOR THERMAL CONDUCTIVITY MEASUREMENTS

The guarded hot-plate apparatus includes the heating plate, cold sinks, edge insulation, metered power supply for the heaters, thermostated circulator for the cold sinks, and thermocouple and power measurement recording system. The ASTM $\mathrm{C}-177$ method presents general instructions, and only improvements for optimum operation of the apparatus are discussed here.

Because commercially manufactured plates were unavailable, a metal-surfaced hot plate was fabricated in our shops to the specifications of ASTM C-177-71. The plate was an 8-in. square by $1 / 4-i n$. thick laminated assembly with a resistance heater etched on a nickel-clad printed circuit board, covered with a clear board, and bonded on both sides with brass plates. The central and guard heaters were located in the center of the laminate so that heat flowed equally to each surface of the plate, with minimum loss to the sides. Temperatures of the surfaces of the plate were sensed by eight thermocouples welded to the surfaces. Their leads were imbedded in channels in the metal surface.

The cold plates were 8-in. square by 1-in. high hollow brass chambers into which thermostated liquid was circulated from a controlled temperature circulator.

In operation, a test stack was assembled in the following order: the bottom cold plate, the bottom sample, the metalsurfaced heating plate, the top sample, and finally the top cold plate. This aligned stack was clamped in a fixture with wing nuts while a load of $11.5 \mathrm{~kg}$ was applied to ensure contact of all surfaces. This stacked assembly was placed in a foamed plastic chamber to which vermiculite insulation was added to insulate the stack.

After all the electrical and plumbing connections were made to the power supply, to readout instruments, and to the temperature controlled circulator, the system was turned on and allowed to reach steady state. By using a data logger with a digital microvoltmeter and printer, rather than a manual potentiometer, it became apparent that materials of low thermal conductivity required a long time, usually overnight, to come to the steady-state conditions required by ASTM C-177. After the test reached steady state and the temperature conditions were in compliance with ASTM-C-177 specifications, the data was then processed. Thermal conductivity 
values were computed, the results were treated statistically, and the averages were compared according to the requirements of the ASTM C-177 method.

The thermal conductivity of samples was calculated by the following equation:

where

$$
k=\frac{q L}{2 A\left(T_{1}-T_{2}\right)}
$$

$$
\begin{aligned}
\mathrm{k}= & \text { thermal conductivity, cal } / \mathrm{s} \\
\mathrm{cm}^{2}\left({ }^{\circ} \mathrm{C} / \mathrm{cm}\right), & \\
\mathrm{q}= & \text { DC volts times amperes } \\
& \text { times conversion factor } \\
& (0.2389), \mathrm{cal}, \\
\mathrm{L}= & \text { thickness of each specimen, } \\
& \mathrm{cm}, \\
\mathrm{A}= & \text { area of central portion of } \\
& \text { heated surface, cm }{ }^{2}, \\
\mathrm{~T}_{1}= & \text { temperature of hot surface, } \\
& { }^{\circ} \mathrm{C}, \text { and } \\
\mathrm{T}_{2}= & \text { temperature of cold sur- } \\
& \text { face, }{ }^{\circ} \mathrm{C} .
\end{aligned}
$$

V. DIFFERENTIAL SCANNING CALORIMETER COMPARATIVE METHOD FOR THERMAL CONDUCTIVITY MEASUREMENTS

To adapt the DSC for making thermal conductivity measurements as described by Brennan, accessories were machined and modifications were made to the base of the removable assembly cover. This was necessary to align and press the unknown and reference samples to assure good contact with the heating and cooling surfaces. A radiation shield ring surrounded the sample and reference. A cold sink was machined of copper with two circular surfaces aligned to fit on top of the sample and the reference. Thermocouples were inserted into wells of the reference and unknown contact surfaces for measuring the sample cold surface temperatures. A button heater was fastened to the top of the cold sink for producing temperatures higher than ambient. A small spring inserted between the top of the cold sink and a cross bar built on the removable assembly cover gave sufficient pressure for good contact between the samples and the heater and cold sink. Heater and thermocouple wires from the cold sink were sealed through outlets in the removable assembly cover, and a seamless canopy of aluminum, fitted over o-rings on the removable assembly cover, sealed the samples in a still atmosphere, or one into which inert gas could be passed by using the DSC system. The cold temperature of the temperature gradient, read on a digital microvoltmeter, was determined from these thermocouples.

The determination of the calibration constant of the instrument also required that the temperature of the heat platens, the hot temperature of the temperature gradient, in an isothermal condition be known accurately. As there was no direct way to fasten thermocouples when the samples were in place, the temperature counter on the DSC control unit was used to indicate the heat platen temperature and was related to the actual temperature by calibration. For heat platen calibration, fine thermocouples were attached to the surface of the platens, and the DSC average, differential, and slope controls were adjusted until there was a relationship between the temperature counter and the temperature of the sample and reference heat platens, both of which were at the same temperature. After calibration at several operating temperatures, a regression line was calculated for the actual temperature of the heat platen as a function of the temperature counter value. This was the high value of the temperature gradient.

with the temperature of the heat platens established, the calorimeter constant at the test temperature, in terms of microcalories per microvolt, was determined by comparing samples of known thermal conductivity. The optimum sample 
cylinder size was determined experimentally to be $6.0-\mathrm{mm}$ diam by $7.5-\mathrm{mm}$ high. A further requirement was that the helght of the unknown and reference be within $0.002 \mathrm{~mm}$ so that the cold sink made total contact on the top surfaces. Because each heater assembly of the DSC has small differences in geometry, resistance, and heat transfer properties, and because each heater platen can be used as a reference, the samples were run twice to cancel these small errors. When the sample was on the left platen and the reference on the right, this was normal mode. When specimens were reversed, this was considered reverse mode. The results so determined were then averaged.

To make a measurement, four steps were required. To null the instrument, duplicate reference samples (usually Teflon) were set on the heater platens at the temperature conditions of the test, and the DSC zero control was adjusted for null output. In the second step, the calorimeter constant was checked by substituting a calibration sample for Teflon on the left heat platen. Next, the unknown sample was substituted for the calibration sample in the left platen (normal mode) and a value determined. In the fourth step, the unknown was run on the right platen (reverse mode) and its thermal conductivity again calculated. The mean of the two values was reported as the thermal conductivity of the unknown. To determine when the experiment was at steady state and to make the calculations in real time, the output of the DSC and the output of the thermocouples were input to a digital microvoltmeter data logger and then transferred to a programmable calculator and printer. With fixed data in the calculator memory and variable data from the DSC, the calculator computed the thermal conductivity of the sample. It was thus possible to determine the thermal conductivity at steady state in a minimum of time.

The equation for calculating thermal conductivity was revised to account for the area-to-helght ratio of both the unknown and reference samples. When the unknown is in the reverse position, the polarity in the equation needs to be specified. The calculator program was written for elther normal or reverse mode when specified at the start of a test. Thermal conductivity was calculated from the following revised equation:

$$
k_{x}=k_{r} \frac{R_{r}}{R_{x}}-\frac{(\mu v)\left(C_{c}\right)}{\left(R_{x}\right)\left(T_{h}-T_{c}\right)}
$$

where

$$
\begin{aligned}
& \mathrm{k}_{\mathrm{x}}=\underset{\mathrm{chermal} \text { conductivity of unknown, }}{\mathrm{cal} / \mathrm{s} \mathrm{cm} \mathrm{cm}^{2}\left({ }^{\circ} \mathrm{C} / \mathrm{cm}\right)} \\
& k_{r}=\text { thermal conductivity of refer- } \\
& R_{r}=\text { ratio of area of reference } \\
& R_{x}=\text { ratio of area of unknown sample } \\
& \mu v=\text { output of digital voltmeter, } \\
& \mu \mathrm{v} \text {, } \\
& \mathrm{C}_{\mathrm{C}}=\text { calorimeter constant, } \mu \mathrm{cal} / \mu \mathrm{v} \text {, } \\
& T_{h}=\text { temperature of hot platen con- } \\
& \mathbf{T}_{\mathrm{C}}=\begin{array}{l}
\text { temperature of cold sink sur- } \\
\text { faces from thermocouples, }{ }^{\circ} \mathrm{C} \text {. }
\end{array}
\end{aligned}
$$

\section{ACKNOWLEDGMENTS}

This will acknowledge the collaboration and help given by F. W. DuBols, who helped explore, discuss, and study efflclent ways of obtalning these values. The help glven by $G$. $W$. Calvert and the late I. K. Edgett in preparing and measuring samples, setting up the guarded hot plate, and monitoring the output of the guarded hot plate before and after its overnight run is also acknowledged. 


\section{REFERENCES}

1. M. J. O'Neill, "Measurement of specific Heat Functions by Differential Scanning Calorimetry," Anal. Chem. 38, 1331-36 (1966).

2. N. Brenner, M. J. O'Neill, "Rapid Determination of Specific Heat," Instrument News 16, No. 2, PerkinElmer Corp., Norwalk, CT (1966).

3. Perkin-Elmer Corp., "Instructions, Specific Heat Kit," Publication 990-9547, Norwalk, CT (1965).

4. D. C. Ginnings and G. T. Furakawa, "Heat Capacity Standards," J. Am. Chem. Soc. 75,522 (1953).

5. C. H. Page and P. Vigoureux, Editors, "The International System of Units (SI)," NBS Special Publication 330, NBS, Washington, DC, 44 (1972).
6. American Society for Testing and Materials, "Thermal Conductivity of Materials by Means of the Guarded Hot Plate, Standard Method of Test for," (ASTM C-177-71), 35, ASTM, Philadelphia, PA (1975).

7. W. P. Brennan, B. Miller, and J. C. Whitwell, "Thermal Conductivity Measurements with the Differential Scanning Calorimeter," J. Appl. Polymer Sci. 12, 1800-1802 (1968).

8. K. Eierman, "Heat Conductivity of Plastics as a Function of structure, Temperature, and Pretreatment," Kunstoffe 51, No. 9, 512-517 (1961).

9. E. S. Watson, M. J. O'Neill, J. Justin, and N. Brenner, "A Differential Scanning Calorimeter for Quantitative Thermal Analysis," Anal. Chem. 36, $1233(1964)$. 
TABLE I

EXPERIMENTAL VALUES OF SPECIFIC HEAT OF EXPLOSIVES

BY DIFFERENTIAL SCANNING CALORIMETER

Name

Composition/Description

Source/Lot

Ammonium picrate

Commercial grade, CTT $215 \mathrm{C}$

WX-2

Comp B-3

RDX $60 \% / T N T 40 \%$

(below melt point)

Holston, Lot 37-16 (6018)

Comp B-3

RDX $60 \% / T N T 40 \%$

(above melt point)

Holston, Lot 37-16 (6018)

HMX

Grade 2, Class D

Holston, Lot SR-22A65 (0306-00)

NQ (Nitroguanidine)

High bulk density

Lot 62-071-21

NQ (Nitroguanidine)

Low bulk density

Lot CCL-10-62I

PETN (Pentaerythritol-

tetranitrate) Superfine

DuPont, Lot 12-9 (0601-02)

Picric acid

Commercial grade, MP $122 \mathrm{C}$

wX-2

Potassium picrate

Commercial grade, CTT 255C

WX-2

PBX 9010-02

RDX $90 \% / \mathrm{Kel}-\mathrm{F} 370010 \%$

Lot 16

PBX 9011-02

HMX $90 \%$ /Estane $574010 \%$

Lot 91-21

PBX 9404-03

HMX $948 / \mathrm{NC} 3 \% / \mathrm{CEF} 38$

Lot 37

PBX 9407

RDX $94 \% /$ Exon $6 \%$

Lot $24-59$ Batch 8

PBX 9501-01

HMX 95\%/Estane 2.5\%/BDNPA-F 2.58

Blend 72-015, PO 33187, (X-0242)

*Not determined

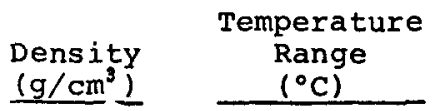

1.730

1.725

*

1.900

1.689

1.651

1.770

1.760

1.930

37 to 237

$0.267+0.00030 T$

1.785

37 to 167

$0.247+0.00064 \mathrm{~T}$

1.772

17 to 167

$0.259+0.00063 T$

1.845

7 to 147

$0.224+0.00070 T$

1.660

37 to 167

$0.241+0.00077 T$

1.835

50 to 175

$0.238+0.00079 T$
0.011

0.007

0.007

0.005

0.006

0.002

std Dev at

Midrange

0.010

0.006

0.009

0.004

0.006

0.009

0.005

0.013 
TABLE I (cont)

Name

Composition/Description

Source/Lot

PBX 9502

TATB $95 \% / \mathrm{Kel}-\mathrm{F} \quad 800 \quad 5 \%$

LASL WX-3 (X-0290)

\section{RDX}

Type B, Class E

Holston, Lot SR 40-57 (0201-00)

TATB (Triaminotrinitrobenzene)

Production grade

Pantex 75-09-10/Cordova 1B034052

TNT

Below melt point (M.P. $80.5^{\circ} \mathrm{C}$ )

Lot WLG 3083, (0101-00)

TNT

Above melt point (M.P. $80.5^{\circ} \mathrm{C}$ )

Lot WLG 3083, (0101-00)

\section{$\mathrm{X}-0217$}

HMX $94 \% / D N P A 2.5 \% /$

BDNPA-F $2.5 \% /$ Wax $1 \%$

94-0l-75

$\mathrm{X}-0219$

TATB $90 \% / \mathrm{Kel}-\mathrm{F} \quad 800 \quad 10 \%$

Batch $16639-49$, PO 32580

$\mathrm{X}-0228$

NO $95 \% /$ Estane $5 \%$

Blend 76-27, PO 37162

$\mathrm{X}-0280$

RDX 95\%/Estane 5\%

$\underline{\left(\mathrm{g} / \mathrm{cm}^{3}\right)}$

Blend 7438, PO 35514

$\mathrm{X}-0290$

TATB 95\%/Kel-F 800 5\%

Pantex/Cordova

$\mathrm{X}-0309$

TNT 74.5/D-2 4.5\%/

Acetylene black $2 \% / A 1 \quad 19 \%$

Destex, PO 37887

$X T X$ 8003-00

PETN $80 \% /$ Sylgard $18220 \%$

Batch 2716

XTX 8004

RDX $80 \% /$ Sylgard $18220 \%$

Batch $4875 \quad(X-0208)$

* Not determined

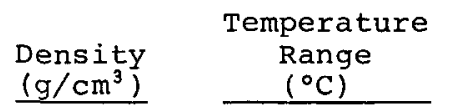

1.900

1.804

1.938

1.654

17 to 67

$0.254+0.00075 \mathrm{~T}$

0.007

97 to 157

$0.329+0.00055 T$

0.002

1.867

27 to 147

$0.239+0.00071 \mathrm{~T}$

0.005

1.907

50 to 275

$0.222+0.00070 \mathrm{~T}$

0.008

1.686

37 to 167

$0.293+0.00066 \mathrm{~T}$

0.005

1.720

50 to 150

$0.221+0.00071 T$

0.003

Std Dev at

Midrange

0.007

0.004

0.002

1.900

37 to 177

$0.249+0.00059 \mathrm{~T}$

0.007

1.707

37 to 67

$0.199+0.00232 \mathrm{~T}$

0.007

1.557

37 to 127

$0.252+0.00085 T$

0.008

1. 538

25 to 187

$0.247+0.00062 \mathrm{~T}$

0.006 
TABLE II

EXPERIMENTAL VALUES OF THERMAL CONDUCTIVITY OF EXPLOSIVES

BY GUARDED HOT PLATE METHOD ASTM C-177

\begin{tabular}{|c|c|c|c|c|c|}
\hline $\begin{array}{l}\text { Name } \\
\text { Composition/Description } \\
\text { Source/Lot }\end{array}$ & $\begin{array}{l}\text { Density } \\
\left(\mathrm{g} / \mathrm{cm}^{3}\right) \\
\end{array}$ & $\begin{array}{c}\text { Mean } \\
\text { Temperature } \\
\left({ }^{\circ} \mathrm{C}\right) \\
\end{array}$ & $\begin{array}{c}\text { Temperature } \\
\text { Difference } \\
\left({ }^{\circ} \mathrm{C}\right) \\
\end{array}$ & $\left(\frac{\mathrm{cal}}{\mathrm{s} \mathrm{cm}^{2}\left({ }^{\circ} \mathrm{C} / \mathrm{cm}\right)}\right)$ & $\left(\begin{array}{l}\mathrm{k} \\
\mathrm{W} \\
\mathrm{m} \cdot \mathrm{K}\end{array}\right)$ \\
\hline $\begin{array}{l}\text { Comp B-3 } \\
\text { RDX } 60 \% / \text { TNT } 40 \% \\
\text { PO } 21749 \quad(6018)\end{array}$ & 1.730 & 46.3 & 22.6 & $5.23 \times 10^{-4}$ & 0.219 \\
\hline $\begin{array}{l}\text { Cyclotol } \\
\text { RDX } 75 \% / \text { TNT } 25 \% \\
\text { PO } 21750(7506)\end{array}$ & 1.760 & 45.9 & 21.8 & $5.41 \times 10^{-4}$ & 0.227 \\
\hline $\begin{array}{l}\text { PBX } 9010 \\
\text { RDX } 90 \% / \operatorname{Kel}-F \quad 370010 \% \\
\text { PO } 21705\end{array}$ & 1.875 & 48.8 & 27.4 & $5.14 \times 10^{-4}$ & 0.215 \\
\hline $\begin{array}{l}\text { PBX } 9011 * \\
\text { HMX } 90 \% / \text { Estane } 5740 \times 210 \% \\
\text { PO } 21706\end{array}$ & 1.772 & 43.4 & 23.4 & $9.08 \times 10^{-4}$ & 0.379 \\
\hline $\begin{array}{l}\text { PBX } 9404 \\
\mathrm{HMX} 94 \% / \mathrm{NC} \quad 3 \% / \mathrm{CEF} 3 \% \\
\text { PO } 21751\end{array}$ & 1.845 & 46.2 & 22.0 & $9.20 \times 10^{-4}$ & 0.385 \\
\hline $\begin{array}{l}\text { PBX } 9501-01-02 \\
\text { HMX } 95 \% / \text { Estane } 5703 \\
\text { F-1 } 2.5 \% / B D N P A-F 2.5 \% \\
\text { LASL WX-3 PO } 32580\end{array}$ & 1.847 & 55.0 & 9.8 & $10.84 \times 10^{-4}$ & 0.454 \\
\hline $\begin{array}{l}\mathrm{X}-0219-00-00-10 \\
\text { TATB } 90 \% / \mathrm{Kel}-\mathrm{F} 80010 \% \\
\text { LASL WX-3 PO } 32580\end{array}$ & 1.907 & 45.5 & 9.3 & $13.23 \times 10^{-4}$ & 0.553 \\
\hline $\begin{array}{l}X-0226 * \\
R D X 89 \cdot 5 \% / \text { Estane } \\
5740 \times 210.5 \% \\
\text { LASL WX-3 PO } 26010\end{array}$ & 1.697 & 48.6 & 26.8 & $5.18 \times 10^{-4}$ & 0.217 \\
\hline
\end{tabular}

*Volume match for comparison of HMX and RDX thermal conductivity. 
TABLE III

EXPERIMENTAL VALUES OF THERMAL CONDUCTIVITY OF EXPLOSIVES

BY DSC-1B COMPARATIVE METHOD

\begin{tabular}{|c|c|c|c|c|c|}
\hline $\begin{array}{l}\text { Name } \\
\text { Composition/Description } \\
\text { Source/Lot }\end{array}$ & $\begin{array}{l}\text { Density } \\
\left(\mathrm{g} / \mathrm{cm}^{3}\right)\end{array}$ & $\begin{array}{l}\text { Mean } \\
\text { Temperature } \\
\left({ }^{\circ} \mathrm{C}\right) \\
\end{array}$ & $\begin{array}{l}\text { Temperature } \\
\text { Difference } \\
\left({ }^{\circ} \mathrm{C}\right) \\
\end{array}$ & $\left(\frac{\mathrm{cal}}{\mathrm{s} \mathrm{cm}^{2}\left({ }^{\circ} \mathrm{C} / \mathrm{cm}\right)}\right.$ & $\left(\frac{\mathrm{k}}{\mathrm{W}}\right)$ \\
\hline $\begin{array}{l}\text { NQ (Nitroguanidine) } \\
\text { Low bulk density } \\
\text { Lot CCL 10-629 }\end{array}$ & 1.651 & 41.3 & 22.7 & $10.14 \times 10^{-4}$ & 0.424 \\
\hline $\begin{array}{l}\text { NQ (Nitroguanidine) } \\
\text { High bulk density } \\
\text { Lot } 62-071-21\end{array}$ & 1.689 & 41.3 & 22.6 & $9.85 \times 10^{-4}$ & 0.412 \\
\hline $\begin{array}{l}\text { PBX } 9502 \\
\text { TATB } 95 \% / K e l-F \quad 800 \quad 58 \\
\text { Pantex TATB } \\
\text { Lot } 75-09 / 10 \quad(X-0290)\end{array}$ & 1.893 & 38.0 & 13.0 & $13.20 \times 10^{-4}$ & 0.553 \\
\hline $\begin{array}{l}\text { TATB } \\
\text { (Triaminotrinitrobenzene) } \\
\text { Pressed into cylinder } \\
\text { TATB } 100 \% \\
\text { Pantex Lot, Blend } 75-09 / 10 \\
\text { PO } 37378\end{array}$ & 1.891 & 38.0 & 13.0 & $12.80 \times 10^{-4}$ & 0.536 \\
\hline $\begin{array}{l}\text { XTX } 8004 \\
\text { RDX } 808 / \text { Sylgard } 182 \quad 208 \\
\text { Batch } 4875 \quad(X-0208)\end{array}$ & 1.540 & 39.8 & 25.5 & $3.42 \times 10^{-4}$ & 0.143 \\
\hline $\begin{array}{l}X-0228 \\
\text { NQ } 958 / \text { Estane } 58 \\
\text { LASL Blend } 76-27\end{array}$ & 1.694 & 42.1 & 21.7 & $10.83 \times 10^{-4}$ & 0.453 \\
\hline $\begin{array}{l}X-0309 \\
\text { TNT } 74.5 \% / D-24.58 / \\
\text { Acetylene black } 28 / \mathrm{Al} 19 \% \\
\text { Destex, PO } 37887\end{array}$ & 1.700 & 40.9 & 23.5 & $8.06 \times 10^{-4}$ & 0.337 \\
\hline $\begin{array}{l}X-0280 \\
\text { RDX } 95 \% / \text { Estane } 58 \\
\text { LASL PO } 35514, \text { Blend } 74-38\end{array}$ & 1.720 & 43.1 & 19.0 & $4.14 \times 10^{-4}$ & 0.173 \\
\hline
\end{tabular}

